\title{
JUDGES AS TORT LAW UN-MAKERS: RECENT CALIFORNIA EXPERIENCE WITH "NEW" TORTS
}

\author{
Stephen D. Sugarman*
}

A straightforward reading of the title captures my central point: in the past dozen years the California Supreme Court has repealed many provisions of tort law that had been adopted by the court in earlier years. The fundamental reason for this turnabout is a change in court personnel with liberal Democrats, led by Chief Justice Rose Bird, generally replaced with moderate or conservative Republicans. I do not dwell on this readily understandable political explanation for the change in the law.

My goals are first, simply to document the extent of the retreat from the court's previously pro-plaintiff inclination. Those who have not been following the court may no longer recognize the California Supreme Court they thought they once knew. ${ }^{1}$ Second, in the process of describing this u-turn, I emphasize the extent to which the new court has rejected some basic outlooks held by the old court on what tort law of the late twentieth-century was supposed to be about. ${ }^{2}$

Finally, I demonstrate an ironic sense in which the new court is creating some "new" torts. ${ }^{3}$ The old court tended to eliminate law, in the

* Agnes Roddy Robb Professor of Law, University of California, Berkeley (Boalt Hall). I thank Gary Schwartz and Bob Rabin who provided helpful comments, and Rebecca Krause who provided helpful research assistance.

1. For a somewhat different appraisal of the work of the new court in the post-Bird era, see Ellis Horvitz, An Analysis of Recent Supreme Court Developments in Torts and Insurance Law: The Common-Law Tradition, 26 Loy. L.A. L. Rev. 1145, 1153-62 (1993).

2. I do not mean to suggest that the California Supreme Court is alone in its shift to a more pro-defendant tort law. See, e.g., James A. Henderson, Jr. \& Theodore Eisenberg, The Quiet Revolution in Products Liability, 37 UCLA L. Rev. 479 (1990) (arguing that the current trend in judicial decisions favors defendants); Gary T. Schwartz, The Beginning and the Possible End of the Rise of American Tort Law, 26 GA. L. Rev. 601 (1992) (arguing that the movement to expand tort liability has ended). California is perhaps an especially important case, however, because its supreme court was clearly one of the nation's most pro-plaintiff as of the end of 1986. Timothy D. Howell, So Long "Sweetheart": State Farm Fire \& Casualty Co. v. Gandy Swings the Pendulum Further to the Right as the Latest in a Line of Setbacks for Texas Plaintiffs, 29 ST. MARY's L.J. 47, 93 (1997).

3. For other writings about "new" torts, see, for example, Anita Bernstein, How to Make a New Tort: Three Paradoxes, 75 Tex. L. Rev. 1539 (1997) (examining "new tort" causes of action and cases); Robert F. Blomquist, "New Torts": A Critical History, Taxonomy, and Appraisal, 95 Dick. L. REv. 23 (1990) (explaining the creation and use of the "new tort" concept). 
sense of overturning defense-oriented "rules" and separate legal "doctrines." The new court, at least in several areas, is doing the opposite by embracing "new" (or older) rules. Hence, in some important respects, it is re-establishing a tort "law" that removes power from juries and returns it to judges (and also tilts in favor of defendants). In light of this shift, one may read my title quite differently: it was the old court that un-made law and the new one that is making it.

For this study, I examined the California Supreme Court's personal injury law decisions for the past fifteen years (1984-1998), and uncovered approximately fifty cases of at least moderate importance-an average of about three per year. I excluded from the study cases involving only property damage, economic loss, defamation and privacy, insurance policy interpretation, as well as others not squarely concerned with physical injuries. No doubt other scholars would add or exclude some cases from my category (or wish I had bounded the category differently), but I am confident that most torts professors would basically agree that I have captured the court's important personal injury law decisions of the past fifteen years. To make one thing clear at the outset, I do not mean generally to endorse or oppose the stance of either the old or the new court.

\section{1984-1986 - THE END OF THE Bird ERA}

At the start of my study period, the court's membership included five appointees of Democratic Governor Jerry Brown and one appointee of his father, Democratic Governor Pat Brown. ${ }^{4}$ Soon the seventh position was filled by the new Republican Governor George Deukmejian. ${ }^{5}$ Only these justices (apart from an occasional temporarily appointed justice) heard and decided the cases handed down in the first three years of my study period. I think it fair to characterize a majority of the justices during this initial period as broadly pro-plaintiff in their approach to tort law; this is especially true of then Chief Justice Bird.

Nine of the approximately fifty cases in my study come from the last three years of the Bird era-1984-1986. Taken as a whole, these decisions reveal a court very willing to expand tort liability for modern policy reasons-primarily that defendants are well-positioned both to protect the public from harm and, when harm does occur, to bear the

4. Governor Jerry Brown's appointees were Rose E. Bird, Otto M. Kaus, Allen E. Broussard, Cruz Reynoso and Joseph R. Grodin. Stanley Mosk was appointed by Governor Pat Brown.

5. The seventh position was filled by Malcolm M. Lucas in 1984. 
burden of compensation by spreading losses through liability insurance and/or via the prices they charge for what they sell.

\section{A. Background}

This pro-plaintiff outlook was not new to the court in 1984. It is more accurate to say that, by 1984 , it was well entrenched. The California Supreme Court's embrace of modern policy reasons in support of defendant tort liability is perhaps best traced to two famous opinions from prior eras. The first is Justice Traynor's 1944 concurring opinion in Escola v. Coca Cola Bottling Co. of Fresno, ${ }^{6}$ in which the former Berkeley law professor argued that a manufacturer should incur "an absolute liability when an article that he has placed on the market, knowing that it is to be used without inspection, proves to have a defect that causes injury to human beings." 7 Traynor openly rested his call for what we have come to term "strict product liability" on a variety of policy considerations, including safety promotion and loss spreading. ${ }^{8}$ Traynor was still on the court nearly twenty years later when his views about the proper legal treatment of defective products were unanimously embraced in Greenman v. Yuba Power Products, Inc. ${ }^{9}$

The second famous opinion I have in mind is that of Justice Peters on behalf of the court in 1968 in Rowland v. Christian. ${ }^{10}$ There, the California Supreme Court overthrew the ancient common law regime that based liability for injuries incurred by those on one's property upon the status of the victim-trespasser, licensee, or invitee. ${ }^{11}$ Not only did the court usher in a new era in which these cases would be decided under basic negligence principles, but also it based the change in the law upon its balancing of a series of considerations (which I call here the "Rowland factors") that plainly included modern policy reasons:

the foreseeability of harm to the plaintiff, the degree of certainty that the plaintiff suffered injury, the closeness of the connection between the defendant's conduct and the injury suffered, the moral blame attached to the defendant's conduct, the policy of preventing future harm, the extent of the burden to the defendant and consequences to the community of imposing a duty to exercise care with

6. 150 P.2d 436 (Cal. 1944) (Traynor, J., concurring).

7. Id. at 440 .

8. See id. at 441.

9. 377 P.2d 897 (Cal. 1962).

10. 443 P.2d 561 (Cal. 1968).

11. See id. at 568. 
resulting liability for breach, and the availability, cost, and prevalence of insurance for the risk involved. ${ }^{12}$

As a doctrinal matter, the Rowland decision still grounds occupier liability in the fault system and not strict liability; yet, the final three considerations on its list of factors to be addressed clearly reflected the thinking of those scholars in the era who were arguing for what has generally been termed "enterprise liability."

Perhaps the most important contribution to that scholarly literature is Guido Calabresi's now famous 1970 book called The Costs of Accidents. ${ }^{13}$ In this and other writings, Calabresi argued against conventional tort law-which he identified with the practice of making a careful inquiry in every case as to whether this particular defendant could reasonably have prevented this particular victim's injury-what one might call "retail" decisionmaking. ${ }^{14}$ Calabresi favored, instead, what I call "wholesale" decisionmaking. One should rather ask whether, in general, for the type of injury involved, defendants or plaintiffs are more likely to be best positioned to know about the risks and to take precautions designed to avoid the accident-a search for what Calabresi called the "cheapest cost avoider."15 Although the costs of some accidents might fall on victims under this approach, it was clear that commercial and governmental actors (i.e., defendants) would far more often be deemed cheaper cost avoiders than individual victims would be. ${ }^{16}$ Moreover, in deciding on whom to place the costs of accidents, Calabresi further argued that one should consider whether defendants or plaintiffs were more likely to be best able to spread the loss, and in particular, to spread the loss in a way that connected the cost to the type of accident involved. ${ }^{17}$ This latter inquiry almost always would point towards injurer liability.

In the thirty years since Calabresi presented his ideas, no state supreme court has fully and openly embraced them, even though some courts occasionally use the phrase "cheapest cost avoider." 18 Nonetheless, I believe that the safety promotion and loss spreading considerations he so well articulated, factors that would lead to "en-

12. Id. at 564 .

13. Guido Calabresi, The Costs of Accidents: A Legal and Economic Analysis (1970).

14. See id. at 251.

15. See id. at 136.

16. See id. at 262.

17. See id. at 284-85.

18. See, e.g., Rankin v. City of Witchita Falls, 762 F.2d 444 (5th Cir. 1985); Union Oil Co. v. Open, 501 F.2d 558 (9th Cir. 1974); Schneider Nat'l, Inc. v. Holland Hitch Co., 843 P.2d 561 (Wyo. 1992). 
terprise liability" in most circumstances, substantially influenced the California Supreme Court throughout the 1970s and for so much of the 1980s as Justice Bird sat on the court.

This influence is well reflected, I believe, in the nine cases I examined from the last three years of the Bird era. Seven of those nine decisions were won by plaintiffs in decisions that expanded tort law in the plaintiffs' direction. Plaintiffs lost two cases and in both of them Chief Justice Bird objected to the majority's opinion on the ground that the court failed to broaden the application of the principle of strict products liability to cover the facts at issue. The seven plaintiff victories all involved efforts to hold defendants responsible for injuries suffered either on the defendants' properties or from use of the defendants' properties. And the reasoning throughout has a decidedly Calabresian bent.

In the next sections, I will briefly describe these three years of decisions, both to provide some doctrinal details and to give the gist of the court's thinking. I have grouped the cases under three headings.

\section{B. Responsibility for the Wrongdoing of Others}

Five of the cases, taken together, may be seen to have consolidated California law around what some might call a "new" tort: you must take reasonable precautions with respect to your property to protect victims from foreseeable wrongdoing by third parties. One way to understand this group of cases is that the court concluded that it would lend its hand to the crime-fighting effort of the day by enlisting property owners in the battle through the threat of tort liability.

The first case involved a "key in the ignition," a problem the court first addressed in 1954 in Richards v. Stanley. ${ }^{19}$ Back then, the court was unsympathetic to the victim's claim against the vehicle owner when an unauthorized third party took the vehicle and injured the plaintiff. In addition to the fact that the owner in Richards had not left his vehicle in a particularly dangerous area, the court seemed to focus on the victim's need to look to the driver, not the car's owner, for recompense. ${ }^{20}$

As a practical matter, however, owners, who usually carry vehicle insurance, are much more likely to be able to provide victim compensation than an unauthorized driver, who might well be a teenage joyrider. Moreover, through the simple precaution of taking the keys away, the driver/owner might easily forestall the injury in the first

19. 271 P.2d 23 (Cal. 1954).

20. See id. at 29. 
place. Ten years later, the court began carving out exceptions to Richards, starting with Hergenrether v. East. ${ }^{21}$ There, the court allowed the jury to impose liability where the "special circumstances" of the case made the defendant's conduct foreseeably quite dangerous. ${ }^{22}$

The court returned to the "key in the ignition" problem in 1984 in Palma v. U.S. Industrial Fasteners, Inc. ${ }^{23}$ The plaintiff claimed that the owner left a commercial truck overnight in a high crime industrial area, unlocked, with the key in the ignition, and that the truck was then stolen and carelessly driven by a third party who ran over the plaintiff. The court pointed to several specific allegations, including the type of people who frequented the area where the truck had been left and the difficulty of safely operating the vehicle, in finding that the defendant should not have been granted a summary judgment and that the plaintiff had a right to have the case heard by the jury. ${ }^{24}$ Although the court did not overrule Richards outright and continued to talk in terms of the "special circumstances" noted in Hergenrether, the opinion makes clear that, as a practical matter, legal analysis of this type of accident was to be brought inside the core of basic negligence law. As the court put it, the factual issue for the jury was simply "whether the circumstance in which [the defendant's] truck was left created a foreseeable risk of harm that was unreasonable and thus imposed on [the defendant] a duty of care to prevent harm to third persons by refraining from creating that risk." 25

This application of general negligence principles to cases where a third party uses the defendant's vehicle to harm the victim was made even more explicit in a second "key in the ignition" case decided at nearly the end of the Bird era. In Ballard $v$. Uribe ${ }^{26}$ the plaintiff offered proof that the defendant knew that his vehicle, an aerial lift, was in need of repair and quite dangerous to use in its existing condition. Yet, according to the victim's witnesses, the defendant left his lift with the keys in the ignition in a place where others could readily gain access to it. Sure enough, the lift was operated by an unknowing coworker of the plaintiff, and when the basket flipped backwards because of the broken condition of the lift, the plaintiff, who had been in the basket, was thrown out and hurt. ${ }^{27}$ The court held that the defendant had a duty to protect others from the operation of its vehicle

21. 393 P.2d 164 (Cal. 1964).

22. See id. at 167.

23. 681 P.2d 893 (Cal. 1984).

24. See id. at 902.

25. Id. at 901 .

26. 715 P.2d 624 (Cal. 1986).

27. See id. at 626 . 
by third parties. ${ }^{28}$ It argued that, given the dangers involved, holding an owner liable for negligently failing to control the unauthorized use of his vehicle benefitted public safety without imposing an undue burden on the owner. ${ }^{29}$

In a separate opinion, Chief Justice Bird called for the outright overruling of Richards..$^{30}$ Although the court concluded that this was not the "occasion to consider the continued vitality of Richards," 31 I believe that, by the time the court is through with Ballard, owners have a general duty, because the vehicles belong to them, to exercise due care to protect victims from injury caused by unauthorized third party use of those vehicles. The jury is to bring to bear, in the specific case, considerations of the size of the risk and the burden of precautions. ${ }^{32}$ The court also made clear that in its deliberations a jury can readily find that, since the burden is so small, an owner may be held liable for leaving his or her keys in the ignition-provided that the circumstances in which the vehicle was left portend significant danger. ${ }^{33}$

Turning now to three other cases involving injuries caused by third party wrongdoers (this time on the defendant's property), we again see the Bird Court brushing aside specific legal requirements of earlier case law. Instead, as with the "key in the ignition" cases, the court embraces the general idea that with the ownership of property comes the duty to protect persons on the property, even from the danger of third party criminals. A breach of that duty depends, in turn, on an individualized determination by the jury in each case of whether a reasonable owner would have taken the specific precaution that the victim identifies as lacking.

First came Peterson v. San Francisco Community College District, ${ }^{34}$ which involved an attempted daytime rape in the parking lot area of the defendant's campus. The student plaintiff alleged that there had been similar attacks in that region of campus that the defendant should have warned her about and that the defendant should have trimmed foliage growing near the stairway where the attack occurred. The court overturned the trial court and held these allegations sufficient to support a claim for "maintaining a dangerous condition of

\footnotetext{
28. See id. at 629.

29. See id.

30. Id. at 640 (Bird, C.J., concurring and dissenting).

31. Id. at 628 n.5.

32. See Ballard, 715 P.2d at 629.

33. See id.

34. 685 P.2d 1193 (Cal. 1984).
} 
public property" under section 835 of the California Tort Claims Act. ${ }^{35}$

In Peterson, the court put aside earlier cases like Hayes $v$. State of California $^{36}$ which generally held that third party conduct does not constitute a "dangerous condition" for which a public entity may be held liable. ${ }^{37}$ In Hayes, where two young men were attacked on a university beach at night, the court applied modern policy analysis in reaching its pro-defendant result. It worried that imposing tort liability could lead to the closure of public facilities, and it belittled the benefits of warnings about crime when the public was already well aware of the risk of violent crime "particularly in unlit and little used places"38

But in Peterson, the court openly applied the earlier-quoted Rowland factors in the other direction, now finding it wholly appropriate for the defendant to have a duty to protect its students from the criminal wrongdoing of third parties. ${ }^{39}$ Emphasizing that the plaintiff had been attacked in a much-used place in broad daylight, the court now argued that warnings would be very beneficial. Adopting what I would call Calabresian analysis, the court said that, "as a community college district responsible for overseeing the campus, the defendant and its agents are in a superior position to know about the incidences of crime and to protect against any recurrences." 40

Next in this line came Isaacs $v$. Huntington Memorial Hospital, ${ }^{41}$ in which a doctor sustained injuries when shot by an unknown assailant in the defendant hospital's parking lot. The case focused on the plaintiff's claim that the defendant hospital should have provided increased security measures in that parking lot. Precisely at issue was whether, in deciding the question of the defendant's duty of care, the court should apply the "prior similar incidents" test that had been required by several previous lower court decisions. ${ }^{42}$

Once again the court applied the Rowland factors and concluded that the jury should decide whether or not to impose liability based upon the "totality of the circumstances." 43 As the court put it, limiting liability to instances of "prior similar incidents" on the defendant's

35. Id. at 1203 .

36. 521 P.2d 855 (Cal. 1974).

37. Id. at 858 .

38. Id.

39. See 685 P.2d at $1200-01$.

40. Id. at 1202 .

41. 695 P.2d 653 (Cal. 1985).

42. See id. at 657.

43. Id. at 661 . 
property violated public policy by discouraging landowners from taking precautions and denying recovery to the first victim. ${ }^{44}$ By contrast, because the danger in this case was clearly foreseeable (the hospital was in a high crime area and thefts and threatened assaults had occurred nearby) and the burden on the hospital of providing adequate security was comparatively low (two lights in the lot where the assault occurred were not working and a security guard and TV camera were used to monitor another of the hospital's lots), the court concluded that the "value to the community of imposing such a duty is manifest." 45

Finally, in Lopez v. Southern California Rapid Transit District ${ }^{46}$ the court held that, under California Civil Code Section 2100, a publiclyowned, common carrier could be liable for injuries sustained when a fight broke out on one of its buses. ${ }^{47}$ Based on the accepted general duty of common carriers to their passengers, the court determined that the carrier could meet its duty with respect to wrongdoing by others by, for example, stopping the bus, requesting the disruptive passengers to desist or leave, or alerting police. ${ }^{48}$ Such precautions would provide considerable public safety while imposing a minimal burden on the carrier. Again, using what I would call Calabresian analysis, the court emphasized the crowded and confining nature of buses and that "passengers have no control over who is admitted on the bus and, if trouble arises, are wholly dependent upon the bus driver to summon help or provide a means of escape." 49 The court went on to say that "[t]hese characteristics of buses are, at the very least, conducive to outbreaks of violence between passengers and at the same time significantly limit the means by which passengers can protect themselves from assaults by fellow passengers." 50

To be sure, the California Supreme Court had earlier broken new ground in holding defendants responsible for the wrongdoing of third parties because of their relationship to either the victim or the third party. For example, that is the general principle underlying cases like Tarasoff $v$. Regents of the University of California ${ }^{51}$ holding therapists potentially responsible for harms caused by their patients, and John-

44. See id. at 655.

45. Id. at 662.

46. 710 P.2d 907 (Cal. 1985).

47. See id. at 914.

48. See id. at 911.

49. Id. at 912 .

50. Id.

51. 551 P.2d 334 (Cal. 1976). 
son v. State of California, ${ }^{52}$ holding state officials potentially liable for harms caused by foster children to their foster parents. The five newer cases I have described from 1984-1986 may be seen to have extended the prior doctrine by seeing the legal duty as arising from the defendant's relationship, not to a person, but to his property.

Another way to see these newer cases is as an extension of Rowland itself. The five cases from 1984-1986 expanded the Rowland rule so that it applies, not only to dangers emanating from the property itself, but also to dangers connected to the property that are created by third parties.

One may argue the results in these cases from 1984-1986 were readily predictable from yet two other earlier California Supreme Court cases-Coulter v. Superior Court ${ }^{53}$ and Weirum v. RKO General, Inc. ${ }^{54}$ Coulter imposed tort duties on social hosts who serve alcoholic beverages to guests who then become drunk and carelessly injure others. Hence, the court there arguably based one's legal responsibility on the connection between your property (your booze) and the wrongdoing of third parties. ${ }^{55}$ Coulter was subsequently overturned by legislation. ${ }^{56}$ Weirum, following Rowland, suggested that an individualized jury determination about risk-taking and prevention might apply to all tort cases cast in negligence, with specific legal rules largely dropping out of the picture. There, the court said that the defendant radio station could be held liable for the misconduct of others who were enticed into their misconduct by the unreasonably dangerous advertising the station ran (awarding prizes to those who were first to physically find an on-the-move disc jockey). ${ }^{57}$

Given these various earlier decisions, I do not want to make too much of the idea that the five cases I have just discussed from 19841986 really do establish a "new" tort. I am confident, however, that they show the court at work as "lawmaker"-candidly examining and relying upon policy reasons for expanding the reach of tort doctrine in various circumstances.

\section{Strict Liability for Product Injuries}

As I mentioned at the start, the California Supreme Court in Greenman had already imposed strict liability on their manufactuers for de-

52. 447 P.2d 352 (Cal. 1968).

53. 577 P.2d 669 (Cal. 1978).

54. 539 P.2d 36 (Cal. 1975).

55. Coulter, 577 P.2d at 675.

56. CAl. Bus. \& Prof. CODE $\S 25602$ (c) (West 1977).

57. Weirum, 539 P.2d at 41. 
fective products. Indeed, it had subsequently extended the principle to cover others involved in the marketing chain, such as retailers ${ }^{58}$ and lessors. ${ }^{59}$ One case from the 1984-1986 period took a giant step in further expanding strict product liability by applying it to landlords. In two other cases, both involving pharmaceutical drugs, the court declined to further expand products liability. Chief Justice Bird dissented in both cases, emphasizing the same policy reasons that drove the court's other decisions from this era.

By imposing strict liability for defects in the condition of rental units, Becker v. IRM Corp. ${ }^{60}$ was perhaps the most venturesome of any of the court's decisions during the $1984-1986$ period. The case involved a tenant falling against a glass shower door which shattered, severely lacerating his arm. ${ }^{61}$ The court held the landlord strictly liable for the injury-treating the door, in effect, as a defective product because it was made of a type of glass prone to shattering. ${ }^{62}$ The court characterized this as a sensible and reasonably logical extension of its earlier applications of strict liability for products. Just as parties involved in the distribution of products are in a better position than consumers to prevent and carry the burden of harm, landlords were seen to be in a better position than tenants to carry the burden of inspection and the cost of injuries. In an openly Calabresian way, the court opined "[ $\mathrm{t}] \mathrm{he}$ cost of protecting tenants is an appropriate cost of the enterprise" and "the landlord ... may be able to adjust rents to reflect such costs." 63

Two other cases from this era also concerned product liability, both involving pharmaceutical drugs. In its earlier decisions, the California Supreme Court seemed determined to expand the principle of strict liability to cover more than manufacturing defects. Even for products manufactured as intended, the court consistently emphasized that California had left negligence principles behind. ${ }^{64}$

Nonetheless, as scholars and other courts soon discovered, it was not obvious what a design or warning defect could be if there were no negligence with respect to the product's design or warning. Put differently, if a court truly rejected negligence in those settings, would it require anything more than the fact that someone was injured? If not, that would seem to equate "defect" with "cause."

\footnotetext{
58. See Vandermark v. Ford Motor Co., 391 P.2d 168 (Cal. 1964).

59. See Price v. Shell Oil Co., 466 P.2d 722 (Cal. 1970).

60. 698 P.2d 116 (Cal. 1985).

61. See id. at 117.

62. See id. at 122.

63. Id. at 124.

64. See Cronin v. J.B.E. Olson Corp., 501 P.2d 1153 (Cal. 1972).
} 
One set of cases concerns dangers that are revealed only after the time of manufacture. Imposing strict liability would mean judging knowledge about the danger at the time of trial rather than at the time of manufacture. This same approach could be applied to newly discovered technological developments, which, if judged as of the time of trial instead of the time of manufacture, would also impose strict liability. Earlier, the California Supreme Court seemed to head down this "hindsight" route in Barker v. Lull Engineering Co., Inc. ${ }^{65}$

It was not clear, however, just why liability should fall on these manufacturers and not on others whose products caused harm but did not experience technological advancements or newly revealed knowledge between the time of manufacture and the time of trial. Moreover, some commentators began to express concern that this hindsight approach would impose inappropriate, uncertain, and potentially crippling liability on manufacturers of products of great social value, such as pharmaceutical drugs. ${ }^{66}$ They pointed out that Dean Prosser himself had sought, in comment $\mathrm{k}$ to Section $402 \mathrm{~A}$ of the Restatement (Second) of Torts, to preclude liability for socially valuable, but unavoidably unsafe, products like prescription drugs. ${ }^{67}$

In Finn v. G.D. Searle \& Co. ${ }^{68}$ the first of two prescription drug cases from the end of the Bird era, the victim suffered visual damage from a drug which was later determined to be harmful. Following a jury verdict for the defendants, the plaintiff appealed. ${ }^{69}$ The court, however, was able to duck the question of whether to apply hindsightbased strict liability to the case because it was clear to the majority that the plaintiff's trial theory was based upon the claim that the defendant knew, or should have known, of the drug's danger at the time the plaintiff took it-a negligence-based notion. On that theory, the court concluded that the plaintiff had a fair hearing by the jury. ${ }^{70}$

Chief Justice Bird disagreed with the court, arguing for the application of strict liability. She emphasized that the policies underlying strict liability in general-deterring poor manufacturing, design, testing, and compensating victims by imposing the cost of injury on the party best positioned to pay-apply equally well to prescription drugs as to other products to which the court had extended strict liability. ${ }^{71}$

65. 573 P.2d 443 (Cal. 1978).

66. See James A. Henderson, Jr., Coping with the Time Dimension in Products Liability, 69 CAL. L. Rev. 919, 921 (1981).

67. See Restatement (Second) of Torts $\$ 402$ A cmt. k (1965).

68. 677 P.2d 1147 (Cal. 1984).

69. See id. at 1151 .

70. See id. at 1154 .

71. Id. at 1164 . 
Bird cited the serious injuries caused by defective drugs, as well as the large numbers of consumers who take them with minimal awareness of possible risks, arguing that a drug manufacturer is in a better position to absorb the costs of injury. According to Bird, a drug manufacturer should be strictly liable whenever a drug fails to meet ordinary consumer safety expectations, or to provide a benefit that greatly outweighs its risk. ${ }^{72}$ Explicitly embracing the hindsight test, Bird advocated basing the manufacturer's knowledge on the information available at the time of trial, not at the time of manufacture. ${ }^{73}$

The second pharmaceutical drug case, Murphy v. E.R. Squibb \& Sons, Inc. ${ }^{74}$ went against a plaintiff (4-3) who sought to hold her pharmacist strictly liable for providing her with a harmful drug. Although some commentators had earlier proposed extending strict liability from products to services, and although some courts had began crossing the line into what appeared to be hybrid product-service cases, the California Supreme Court, having just taken one large step in imposing strict liability on landlords in Becker, refused to take the next giant step in Murphy. ${ }^{75}$ Instead, the court analogized a pharmacist's role of dispensing drugs to a service like manufacturing blood plasma which was protected against strict liability by Section 1606 of the California Health and Safety Code. ${ }^{76}$ The court also relied on policy grounds, stating that "if pharmacies were held strictly liable for the drugs they dispense, some of them, to avoid liability, might restrict availability by refusing to dispense drugs which pose even a potentially remote risk of harm, although such medications may be essential to the health or even the survival of patients" or by selecting "the more expensive product made by an established manufacturer when he has a choice of several brands of the same drug." 77

Chief Justice Bird, joined by Justices Broussard and Kaus, dissented, finding that the pharmacist's role as salesman predominates his or her role as service provider. ${ }^{78}$ Moreover, she argued, in Calabresian style, that applying strict liability to pharmacists would serve all the policies served by strict liability in general-by encouraging the pharmacist to take precautions, as well as preventing the indi-

72. Id. at 1168 .

73. $I d$.

74. 710 P.2d 247 (Cal. 1985).

75. See id.

76. See id. at 252.

77. Id.

78. Id. at 258 (Bird, C.J., dissenting). 
vidual unlucky patient from having to bear the financial burden of his or her own injuries. ${ }^{79}$

Summing up these product liability decisions, many would say that Becker established a "new" tort. In any event, what I see is a court carefully considering new policy proposals put before it in the products liability area, and deciding, much like a legislature, whether it would, on balance, be wise to sharply expand defendant responsibility. One large step in that direction was taken and two other steps were put off, at least for the time being.

\section{Responsibility for the Negligent Infliction of Emotional Distress}

The remaining case from the end of the Bird era that I will discuss involved the negligent infliction of emotional distress ("NIED") upon a family member based on harm occurring to a child. The California Supreme Court broke ground on NIED claims nearly twenty years earlier in Dillon v. Legg, ${ }^{80}$ which allowed recovery in certain circumstances by those who witness a close relative's harm. Ochoa v. Superior Court ${ }^{81}$ was one of several cases that had come before the California courts since then, asking the court to determine the boundaries of an NIED cause of action. In Ochoa, the Bird Court liberalized the boundary by allowing a mother to recover for the emotional distress she suffered when watching her son deteriorate from the lack of proper medical attention while he was held in a juvenile hall infirmary. ${ }^{82}$

Before Ochoa, however, an NIED claim seemed to require a "sudden occurrence" of harm; the court now concluded that such a requirement "arbitrarily limits liability when there is a high degree of foreseeability of shock to the plaintiff and the shock flows from an abnormal event, and, as such, unduly frustrates the goal of compensation-the very purpose which the cause of action was meant to further." ${ }^{3}$ Hence, Ochoa portended the possibility that, à la Rowland, juries might soon decide all NIED cases on a case-by-case basis in terms of the foreseeability of harm under the specific circumstances.

\section{E. Overall}

As noted already, the seven plaintiff victories in the 1984-1996 period generally reflect Calabresi's ideas. Becker, which extended strict

79. Id.

80. 441 P.2d 912 (Cal. 1968).

81. 703 P.2d 1 (Cal. 1985).

82. Id. at 9 .

83. Id. at 7 . 
liability to landlords for defective shower doors, surely does. Landlords, more than new tenants, are plainly better positioned to know and do something about replacing dangerous shower doors and other dangerous conditions in the apartment. In any event, through rent, landlords can spread across all tenants the cost of inevitable accidents from shower door injuries to unlucky victims.

Although couched in the language of negligence law, I think cases like Lopez, Isaacs, and Peterson also reflect this Calabresian outlook. These commercial or governmental property owners and operators are much better positioned than individual victims to take precautions to prevent injury by third-party wrongdoers. These property owners can also spread the cost of accidents over the prices they charge for their activities, whether it is for bus fares, parking lot fees, or college tuition.

To be sure, victims in these sorts of cases were supposed to prove that the proposed safety precautions were not only feasible, but would really have made a difference-the sort of retail decisionmaking that Calabresi opposed. This evaluation, of course, was to be made by jurors-participants who, at the time, many observers suspected were all too willing to impose costs on corporate and governmental defendants without being too picky about the subtleties of tort law's fault requirement.

This point leads me to another over-arching theme. Writing in the early 1970 s, Harry Kalven, in many respects an ideological opponent to Calabresi, observed that tort law was becoming simplified and stream-lined.84 Courts were tossing aside many of the old specific "rules" of tort law. Rowland was perhaps the most prominent example-scuttling complex rules about the law of occupier liability to invitees, licensees, and trespassers. ${ }^{85}$ From all around the nation there were many other cases in this same vein-especially those that cast aside old "no duty" rules, including, for example, cases that eliminated so-called spousal immunity, ${ }^{86}$ brushed aside automobile "guest statutes," 87 and recognized rights of consortium in both spouses. ${ }^{88}$ Kalven seemed to applaud this development, although he noted it was ironic that, just as minor irregularities and inconsistencies of tort law

84. See, e.g., Harry Kalven, Jr., Tort Watch, 34 ATLA L.J. 1 (1972) (commenting on the growth of strict liability) [hereinafter Kalven, Tort Watch]; Harry Kalven, Jr., Negligence on the Move, 33 ATLA L.J. 1 (1971) (commenting on the growth in the law within the negligence principle).

85. Rowland v. Christian, 377 P.2d 897 (Cal. 1968).

86. See Waite v. Waite, 618 So. 2d 1360 (Fla. 1993).

87. See Brown v. Merlo, 506 P.2d 212 (1973).

88. See Diaz v. Eli Lilly \& Co., 302 N.E.2d 555 (1973). 
were being eliminated, there was developing an enormous inconsistency in tort law-with some domains governed by the fault principle and others by the principle of strict liability. ${ }^{89}$

The practical result of the elimination of many of these old rules (seen most clearly in the occupier liability area) was to transfer much power from judges to juries. To be sure, judges, at least in theory, could still grant summary judgments and directed verdicts in appropriate individual cases. But these hurdles were usually easy to jump, perhaps in part as a result of the increased sophistication of the plaintiff's bar and the growing availability of expert witnesses who would say just about anything. In short, the purification of the negligence regime increasingly meant that the law was what an individual group of jurors said it was. In its favor, this trend had, among other things, a kind of egalitarian spirit to it that well fit the thinking of many 1960s liberals.

Whether or not surreptitiously intended as a way of creating strict liability, many of the Bird Court's decisions I have discussed pushed California tort law in this "lawless" direction as well. This substitution of jury decisionmaking for judge-applied legal rules is clearly seen in cases like Ochoa, ${ }^{90}$ Isaacs, ${ }^{91}$ and the "key in the ignition cases." 92 Again, each generally moved those sorts of cases out of the hands of judges into the hands of juries. ${ }^{93}$

As an aside, there is one final case from this era that I cannot resist mentioning, even though it is outside my category. Seaman's Direct Buying Service, Inc. v. Standard Oil of California ${ }^{4}$ capped an important series of earlier decisions by the California Supreme Court that viewed defendants as having abused their positions under contract law. These included employers who wrongfully discharged employees, insurers who wrongfully refused to pay valid claims, landlords who wrongfully evicted tenants, and so on. ${ }^{95}$ Seaman's involved the wrongful refusal to acknowledge the existence of a contract. ${ }^{96}$ Not

89. Kalven, Tort Watch, supra note 84 , at 2.

90. As discussed in supra Section D. Ochoa rejected Dillon's rules for individualized inquiries in NIED cases.

91. See supra Section B for Isaacs rejection of "prior similar incidents" for a "totality of the circumstances" test.

92. Ballard v. Uribe, 715 P.2d 624 (Cal. 1986); Palma v. U.S. Indus. Fasteners, 681 P.2d 893 (Cal. 1984).

93. I do not mean to argue that all of the Bird-era cases I reviewed are of this sort. Becker $v$. $I R M$, for example, took the issue of individualized fault determination away from the jury by imposing strict liability on the landlord. See Becker v. IRM Corp., 698 P.2d 116, 122 (Cal. 1985).

94. 686 P.2d 1158 (Cal. 1984).

95. See id. at 1166.

96. See id. 
wanting to limit victims to their conventional contract rights, the court adopted the "bad faith" concept that, when violated, constituted a tort, thereby providing victims with access to both compensatory pain and suffering damages and punitive damages. ${ }^{97}$ Many would say this "bad faith" area of the law amounts to a "new" tort.

In sum, though perhaps not amounting to gigantic expansions of tort law, the California Supreme Court cases I have reviewed from the 1984-1986 period surely constitute definite extensions of the law. Even if not "new" torts, the pro-plaintiff decisions certainly represent the embracing of new legal duties, particularly for landlords, vehicle owners, and other property owners.

\section{The Past Twelve Years - The Post-Bird Era}

\section{A. The Voters Refuse to Retain}

Under California Law, the governor appoints supreme court justices, but the voters must later approve them for new terms in periodic "retention" elections. ${ }^{98}$ Three pro-plaintiff judges, Chief Justice Bird and Associate Justices Reynoso and Grodin, came up for retention simultaneously in 1986. In a bitter election, fought in public primarily over "death penalty" issues, the voters rejected these justices and thereby removed them from the court. Other justices promptly replaced them, and with that came an abrupt change in the ideological stance of the court as a whole.

By March of 1987 the only Democratic-appointed justices left on the court were Justices Mosk and Broussard, and the latter retired in 1991. Today, Justice Mosk soldiers on, having now served for thirtyfive years since his appointment by Governor Pat Brown in 1964. By now, all but two of Governor Deukmejian's eight appointees have also left the bench, having been replaced by four appointees of Republican Governor Pete Wilson.

\section{B. Reversing Gears}

I have identified about forty personal injury decisions of the California Supreme Court from the past twelve years that I consider to be at least moderately important. Taken as a whole, they present a dramatically different picture from the one painted so far. Plaintiffs did not lose every one of these cases, but they lost most of them. Some decisions involved the court's refusal to expand tort law further.

97. See id. at 1167.

98. See Cal. Const, art. 6(a), § 16 (1966). 
Many involved retrenchment from earlier positions. Several cases openly overruled highly visible decisions of the Bird era.

Taken as a whole, the cases decided by the California Supreme Court in the past twelve years, in my judgment, reflect a very different outlook on tort law than we saw under Chief Justice Bird's leadership. First, although the court still faithfully rehearses the Rowland factors, it now frequently draws very different conclusions about the direction they point. Simply put, the court now broadly opposes the imposition of liability on a defendant on the grounds that he either is well positioned to spread the cost of the accident or, as a general matter, is probably better positioned to avoid the accident. In short, Calabresian "enterprise liability" thinking is out of favor with the court. Second, the court is now strongly inclined to re-introduce more detailed rules into tort law-to take power back for judges and away from juries (and thereby to give defendants clearer ideas about just what their precise legal obligations are).

In this latter respect, we are confronted with the nice linguistic irony that I noted at the outset: as the court has been cutting back on the reach of tort law, it has made much new law in the sense of substituting "rules" for "jury discretion." 99 These are the main themes I will illustrate as I skate over approximately forty personal injury law decisions of the California Supreme Court since 1986. As in Part I, my analysis groups these more recent cases under several headings.

\section{Taking Responsibility for the Mis-Conduct of Others}

As before, I will start with the issue of taking responsibility for the wrongdoing of third parties. Here, in two important decisions, the California Supreme Court has sharply shifted gears by taking a strong pro-defendant stance.

In Ann M. v. Pacific Plaza Shopping Center, ${ }^{100}$ an employee in the defendant's shopping center, who had been raped by a stranger, charged that the defendant was negligent in not providing security guards. As Justice Mosk emphasized in his dissent, the court essentially scuttles the "totality of the circumstances" test of Isaacs and resurrects the "prior similar acts" test. ${ }^{101}$ The court stated that because there were no prior similar incidents on the defendant's property, this limited the foreseeability of the danger, and so the precaution re-

99. Again, I do not want to be understood as arguing that the court is doing this in every case-as I will point out below.

100. 863 P.2d 207 (Cal. 1993).

101. See id. at 216. 
quested by the victim was too burdensome. ${ }^{102}$ While the court tries to cast its evaluation as a matter of the defendant's legal "duty" (an issue for judges), this, of course, is exactly the sort of determination that the Bird Court sought to give to juries in Isaacs. Ann M. is additionally notable for the court's open assertion that "random, violent crime is endemic in today's society. It is difficult, if not impossible, to envision any locale open to the public where the occurrence of violent crime seems improbable."103 This reflects a very different attitude than that of the Bird Court about what is realistic to expect landowners to do to prevent crime.

In Kentucky Fried Chicken of California, Inc. v. Superior Court, ${ }^{104}$ the plaintiff alleged that she was a customer in the defendant's restaurant when an unidentified criminal seized her and held her at gunpoint, threatening to harm her if the employee at the cash register did not give him money. When the employee failed promptly to comply, the criminal threatened to shoot the plaintiff, who screamed out in fear for her life. Only then did the clerk open the cash register drawer, after which the criminal took the money and ran. Although the plaintiff was not shot, she claimed serious injury. The court held that the defendant had no legal duty to comply with the robber's unlawful demands, emphasizing the defendant's legal right to defend his own property. ${ }^{105}$ Once more, the court takes for itself the question of whether it should impose certain safety precautions (to protect customers from crime) on corporate defendants, and once again concludes it should not. ${ }^{106}$ Again, this is quite inconsistent with the Bird Court's approach in Isaacs and Peterson which turned these matters of reasonably required safety measures over to the jury.

Not all of the court's post-Bird decisions involving responsibility for the wrongdoing of third parties were decided for defendants, however. A pair of decisions imposes a duty based upon "negligent misrepresentation."

First came Garcia v. Superior Court, ${ }^{107}$ where a convicted murderer on parole kidnaped and killed the plaintiffs' mother. They claimed that the defendant parole officer knew that the murderer had threatened to kill their mother but nevertheless told her that he would "not come looking" for her. ${ }^{108}$ The court concluded that an action

102. See id. at 215-16.

103. Id. at 215 .

104. 927 P.2d 1260 (Cal. 1997).

105. See id. at 1269 .

106. See id. at 1262 .

107. 789 P.2d 960 (Cal. 1990).

108. See id. at 962. 
would lie if the jury was convinced that the defendant had "negligently misrepresented" the risk to the mother. ${ }^{109}$ Next came Randi W. v. Moroc Joint Unified School District, ${ }^{110}$ where the plaintiff, a student, alleged that she was sexually assaulted by someone who had been the subject of prior charges of sexual misconduct. According to the plaintiff, her school district had hired her assailant because his prior school districts employers gave him unqualified positive references even though they knew about the sexual impropriety complaints against him. ${ }^{111}$ Consequently, she sued those former employers, and the court held this stated a cause of action for negligent misrepresentation, relying upon Garcia. ${ }^{112}$

Hence plaintiffs in both Garcia and Randi W. were permitted to hold their defendants liable for the criminal wrongdoing of third parties-provided, of course, that they could prove at trial the allegations of their complaints. Two points are worth noting about the limited nature of the duties imposed in these cases. First, if the defendant parole officer and school districts had just kept quiet, there would apparently have been no basis for imposing liability upon them for not disclosing what they knew about the dangerousness of the third party in question. It was their affirmative misrepresentation of the danger that created potential liability. Second, plaintiffs in both cases were also required to show that the misrepresentation was actually relied upon-by the victim herself in Garcia and by the hiring school district in Randi $W$. The more pro-plaintiff dissenters in both cases offered analyses that would not have required that reliance.

Next, I want to turn to quite different tort law settings in which doctrine can serve the purpose of making one party responsible for the fault of another. For example, in Privette v. Superior Court, ${ }^{113}$ a worker, who sustained injuries when instructed by an independent contractor to carry hot tar up a ladder, sued the property owner. The court stated that "under the peculiar risk doctrine, a person who hires an independent contractor to perform work that is inherently dangerous can be held liable for tort damages when the contractor's negligent performance of the work causes injuries to others."114 In effect, this doctrine treats the independent contractor as though he were an employee by imposing vicarious liability on the defendant. Another

109. See id. at 965.

110. 929 P.2d 582 (Cal. 1997).

111. See id. at 584 .

112. See id. at 587.

113. 854 P.2d 721 (Cal. 1993).

114. Id. at 723 . 
way to put this rule is to call it a "non-delegable duty." Ever since Woolen v. Aerojet General Corp., 115 California law had permitted employees of the independent contractor to invoke the "peculiar risk" doctrine.

In Privette, however, the court overruled that longstanding precedent, essentially on the grounds that the victim's access to workers compensation benefits should be his exclusive remedy. ${ }^{116}$ Put differently, it saw the old rule as providing access to a deep pocket, one that the court concluded was not really necessary when workers compensation was already available. The court also thought it unfair that the defendant who was not at fault would have greater responsibility to the victim than the careless independent contractor, against whom no tort claim by the victim, or claim for indemnity from the defendant, would lie. ${ }^{117}$ Of course, a parallel situation sometimes applies in other workplace settings in which the employer is at fault and the employee sues a third party, such as a manufacturer who is held strictly liable for a defective product. ${ }^{118}$

Cutting off access to a second deep pocket through tort law when workers compensation is available has been a recurring theme for the new court. For example, in Cole v. Fair Oaks Fire Protection District, ${ }^{119}$ the court decided that when a worker suffers a physical injury, workers compensation provides the exclusive remedy. ${ }^{120}$ Thus the worker may not sue the employer in tort for emotional distress, even if tort law would compensate damages when workers compensation does not. ${ }^{121}$

115. 369 P.2d 697 (Cal. 1962).

116. 854 P.2d at 731 .

117. See id. at 728 .

118. In Toland v. Sunland Housing Group, 955 P.2d 504 (Cal. 1998), the court reaffirmed and slightly expanded the reach of Privette.

119. 729 P.2d 743 (Cal. 1987).

120. Id. at 744 .

121. See also Livitsanos v. Superior Court, 828 P.2d 1195, 1197 (Cal. 1992). In Livitsanos, the court expanded Cole to cover situations in which emotional distress damages were sought in tort and no physical injury was alleged. $I d$. Still, workers compensation was to be the victim's only remedy even if it provided no compensation. Later, the court eased up a bit on the "exclusive remedy" rule both in Snyder v. Michael's Stores, Inc., 945 P.2d 781, 782 (Cal. 1997) (holding that the exclusive remedy principle did not bar a claim by a child who was in utero when allegedly injured from her mother breathing carbon monoxide while at work) and Fermino v. Fedco, Inc., 872 P.2d 559, 560 (Cal. 1994) (concluding that a claim for false imprisonment was not barred by workers' compensation law).

For another example of the new court restricting access to a deep pocket, see Evangelatos $v$. Superior Court. 753 P.2d 585 (Cal. 1988). There, in passing, the court (albeit in dicta) seems to have abandoned the position taken earlier in American Motor Cycle v. Superior Court, 578 P.2d 899 (Cal. 1978), as to how the risk of insolvency is to be born in cases with multiple tortfeasors. Evangelatos, supra at 590. In American Motor Cycle, the court seems to say that the California 
Conventional vicarious liability of employers for the torts of their employees is, of course, another setting in which the doctrine of strict liability applies and serves, among other things, to give the victim access to a presumptively deeper pocket. It also arguably gives additional safety incentives to those who are "cheaper cost avoiders" than the victims. The court in recent years has confronted several difficult vicarious liability cases involving intentional sexual misconduct by employees.

In John R. v. Oakland Unified School District, ${ }^{122}$ the court held vicarious liability was inapplicable when a junior high school pupil was allegedly sexually molested by his math teacher, in the teacher's apartment, while participating in an officially sanctioned extracurricular program. The doctrinal issue in these sorts of cases has traditionally been cast as whether the tort was committed "within the scope of employment." 123 At the time of John R. there was a division of opinion as to how to treat sexual assaults by employees-both in courts around the nation and in the lower California courts.

The new court decided in favor of the defendant in John R. after exploring the policy goals underlying vicarious liability. A Calabresian analysis would probably impose vicarious liability on both loss spreading and safety promoting grounds. But the California Supreme Court asserted that loss spreading was inappropriate here both because it would make insurance more difficult for already-strapped school districts to obtain and because this injury was not fairly part of the risk allocable to the district. ${ }^{124}$ The court was equally skeptical about the accident prevention rationale, claiming that "strict liability in this context would be far too likely to deter districts from encouraging, or even authorizing, extracurricular and/or one-on-one contacts between teachers and students or to induce districts to impose such rigorous controls on activities of this nature that the educational process would be negatively affected." 125

In Farmers Insurance Group v. County of Santa Clara, ${ }^{126}$ the court put forward essentially the same policy analysis, holding that the

rule was that the solvent defendants would be responsible for any share of the loss otherwise assigned to an insolvent defendant-and that no part of the insolvency would be born by the victim, even at-fault victims. But with no discussion, Evangelatos embraces the view (supported by some subsequent lower California decisions) that the risk of insolvency would also be proportionately shared by any plaintiff who was also at fault. Evangelatos, supra at 595.

122. 769 P.2d 948 (Cal. 1989).

123. Id. at 953 .

124. See id. at 956.

125. Id.

126. 906 P.2d 440 (Cal. 1995). 
county was not responsible for the acts of a deputy sheriff who lewdly propositioned and offensively touched other deputy sheriffs. ${ }^{127} \mathrm{Fi}$ nally, in Lisa M. v. Henry Mayo Newhall Memorial Hospital 128 the court, focusing more this time on issues of basic fairness, held that a hospital was not vicariously liable for the conduct of a hospital technician who sexually molested a patient under the pretense of conducting an ultrasound examination. ${ }^{129}$

Oddly enough, despite these three pro-defendant rulings, the court, in Mary M. v. City of Los Angeles ${ }^{130}$ (decided after John R. but before Farmers and Lisa $M$.) concluded that a city could be held vicariously liable for the conduct of its police officer who raped a woman he had detained and taken to her home. ${ }^{131}$ The court held that when a police officer detains a person and then misuses his authority while she is in his custody, it is the jury's decision to find whether he was acting within the scope of his employment. ${ }^{132}$ In contrast to John R., the court in Mary $M$. rejected the claim that liability would generate a perverse behavioral response by the defendant; to the contrary, it asserted that vicarious liability might actually lead to socially desirable prevention measures by the police department. ${ }^{133}$ I will not try to reconcile these four vicarious liability decisions, which were all decided by a divided court with a changing membership. Rather, I will simply note that, if nothing else, the difficulties the court had with these cases at least shows that sweeping "cheapest cost avoider" and "cheapest loss spreader" considerations are clearly insufficient to create liability.

This trend appears in other cases as well, including two in which the court refused to impose a duty on the defendant to take responsibility for harms to victims that were more directly caused by a party other than the defendant. In Nally v. Grace Community Church of the Valley, ${ }^{134}$ the parents of a young suicide victim sued a large, wealthy church when one of its clergymen failed to prevent the suicide through religious counseling. The church could easily be viewed as the "cheapest cost avoider" and surely the "cheapest loss spreader" in this situation, and yet the court declined (for arguably very good reasons) to impose liability on the basis of an alleged negligent performance of

127. See id. at 444.

128. 907 P.2d 358 (Cal. 1995).

129. Id. at 359.

130. 814 P.2d 1341 (Cal. 1991).

131. See id. at 1342.

132. See id. at 1352.

133. See id. at 1348.

134. 763 P.2d 948 (Cal. 1988). 
spiritual counseling. ${ }^{135}$ In Artiglio v. Corning, Inc., ${ }^{136}$ plaintiffs sought to hold Dow Chemical liable for injuries alleged to have been caused by silicone breast implants manufactured by its partially owned, and now bankrupt, subsidiary Dow Corning. Their case was based upon the theory that when Dow Chemical had "undertaken" certain research and testing activities, this created an ongoing obligation for it to take responsibility for the safety of the product in question. ${ }^{137}$ Dow Chemical was certainly a "cheaper loss spreader" than the plaintiff and because of its expertise in product testing, an apparently far superior source of accident prevention. Yet, the court showed no interest whatsoever in deciding this case at the wholesale level, finding instead that, as a matter of law, the risk of harm to these plaintiffs was unforeseeable when Dow Chemical had undertaken those specific instances of silicone research and testing in the past, and hence the grant of defendant's summary judgment motion was proper.

\section{Strict Product Liability}

I turn next to the core of products liability, where the retreat from prior law is stark. Perhaps most strikingly, in Peterson v. Superior Court, ${ }^{138}$ the new California Supreme Court simply overruled Becker. There, a hotel guest was injured by slipping on the surface of an allegedly defective bathtub. Portions of the opinion read very much like the report of a legislative committee that has decided a previous law has not worked out very well, or perhaps even more like the report of a legislative committee whose minority has recently become its majority. Noting that California had stood virtually alone in imposing strict liability on landlords, the new court membership claimed that "only in rare cases would the imposition of strict liability upon the landlord or hotel owner create an impetus to manufacture safer products." 139 As for the question of which party was more likely to discover the defect, the court focused in on the issue at the retail level, asserting "a tenant cannot reasonably expect that the landlord will have eliminated defects in a rented dwelling of which the landlord was unaware and which would not have been disclosed by a reasonable inspection." 140 Moreover, the new court sounded very wary of simply providing another deep pocket (a good loss spreader) for the innocent victim of a

135. See id. at 952.

136. 957 P.2d 1313 (Cal. 1998).

137. See id. at 1318.

138. 899 P.2d 905 (Cal. 1995).

139. Id. at 915 .

140. Id. at 918 . 
product defect to sue-a theme we saw already in the third party wrongdoer cases just discussed and will encounter again and again below. In short, the victim was relegated back to negligence law so far as the landlord is concerned-although the victim could still pursue the bathtub maker in strict liability.

This Peterson decision is but one example of the court's retrenchment on products liability. In several other cases, with import both large and small, the court (despite some rhetoric to the contrary) is slowly, but steadily, pushing California products liability law away from any remaining pretense of strict liability into a decidedly faultbased framework (apart from routine manufacturing defect cases).

In Brown v. Superior Court, ${ }^{141}$ the court rejected the application of its then basic products liability doctrine as articulated in Barker. Brown was a DES case which clearly involved a product that surprised the plaintiff by turning out to be dangerous. ${ }^{142}$ The court first decided that Barker's "consumer expectations" test was inapplicable because, with pharmaceutical drugs, the consumer's expectations are based on the doctor's warnings, not the drug itself, and a manufacturer should not be liable for a doctor's failure to warn. ${ }^{143}$ The court also cited public policy reasons for not imposing strict liability on the manufacturer based on the "consumer expectations" test, asserting that, in the case of drugs, it would result in marketing delays or reluctance on the part of manufacturers to develop new drugs. ${ }^{144}$ Second, the court rejected the applicability of strict liability via the "hindsight" test to the defective warning aspect of the case-saying that the defendant could not be held liable for "risks inherent in a drug ... it neither knew nor could have known by the application of the scientific knowledge available at the time of distribution." 145 In short, drug makers would be held to something that sounds to me very much like the fault principle-thereby, laying aside the uncertainty that remained after Finn.

After Brown, the court decided Anderson v. Owens-Corning Fiberglas Corp. ${ }^{146}$ an asbestos case. I find this opinion something of an indecipherable mish-mash. The court claims that it is continuing to apply strict liability to non-drug warning cases because the defendant is to be precluded from arguing that it was reasonable to fail to disclose dangers known to it at the time of manufacture. ${ }^{147}$ Of course, it

141. 751 P.2d 470 (Cal. 1988).

142. See id. at 473.

143. See id. at $476-77$.

144. See id. at 478.

145. Id. at 480 .

146. 810 P.2d 549 (Cal. 1991).

147. See id. at 559. 
would almost always be negligent to fail to disclose any substantial known danger; the more important issue was what to do about unknowable dangers. As to that, the court clearly rejected the "cheapest loss spreader" ideology that seemed to underlie decisions of the Bird era. ${ }^{148}$ It admitted that although "an important goal of strict liability is to spread the risks and costs of injury to those most able to bear them ... it was never the intention of the drafters of the doctrine to make the manufacturer or distributor the insurer of the safety of their products." 149 By emphasizing "How can one warn of something that is unknowable?"150 the court clearly rejects Calabresi's wholesale approach which would surely view chemical manufacturers as generally far more likely than chemical users to find out in advance about the dangers of their products and take actions to prevent injuries. As for loss spreading, the court makes the point in Anderson that, when the risk is unforeseeable, even large corporations might well be unable to spread losses widely. ${ }^{151}$ Moreover, although the court argues that its embrace of fault-based responsibility for warning defects is to be distinguished from how California law treats design defects, as we will see next, the court has now largely imposed a negligence-like approach there as well.

In Soule v. General Motors Corp., ${ }^{152}$ the plaintiff's ankles were badly injured when her car collided with another vehicle. She claimed that her GM car was defective because its left front wheel broke free, collapsed rearward, and smashed the floorboard into her feet. ${ }^{153}$ The plaintiff made two main legal claims-that her car had been improperly welded (manufacturing defect) and that Ford had a better safety design that GM should have adopted (design defect). ${ }^{154}$ GM disputed both of these points. Over GM's opposition, the trial court charged the jurors that they could find for the plaintiff on the "consumer ex-

148. The Bird era, led by Chief Justice Rose Bird, repealed many provisions of tort law previously adopted by the court.

149. Anderson, 810 P.2d at 559.

150. Id.

151. Id. at 559 n.14. I do not believe that my position as to the state of "warning" law in California after Anderson is undermined by Carlin v. Superior Court, 920 P.2d 1347 (Cal. 1996), a subsequent pharmaceutical drug case about warnings decided by a panel including three temporarily-assigned lower court judges. Although Justice Mosk's opinion for the court again tried to make a big deal of the difference between failure to warn in the strict liability context and the negligence context, this still seems of little moment to me. Basically, the court concluded that a drug maker could be liable for the "failure to warn about the known or reasonably scientifically knowable dangerous propensities of its product." Id. at 1348 . This is a restatement of the holding in Anderson, and still basically sounds like negligence to me.

152. 882 P.2d 298 (Cal. 1994).

153. See id. at 301.

154. See id. at 302. 
pectations" test-a test that, if applied to GM in this setting, could clearly be used to impose liability without fault on the carmaker. ${ }^{155}$ Expanding the reach of Brown beyond pharmaceutical drugs, the California Supreme Court decided that "the consumer expectations test is reserved for cases in which the everyday experience of the product's users permits a conclusion that the product's design violated minimum safety assumptions"156-a condition absent from this case. Instead, the court said that these sorts of cases, where there realistically are no consumer expectations about wheel collapses in crashes, must be evaluated under the risk/benefit test. ${ }^{157}$

To be sure, the court in Soule explicitly refused to overrule the consumer expectations test for all cases, as GM had pressed and some other states have done. ${ }^{158}$ Indeed, the court made clear that doing so would mean, in effect, relegating all design defect cases to negligence law-something it was unwilling to do, at least at the time. Furthermore, the court also rejected GM's effort to reverse California's law that imposed the burden of proof with respect to design defects on the defendant. ${ }^{159}$ Nevertheless, it seems to me that for a great number of complex products, Soule, as a practical matter, turns the trial of design defect cases in California into proceedings virtually indistinguishable from what they would be were the plaintiff required to prove design negligence. ${ }^{160}$

The new dominance of a fault orientation in the product liability arena may also be seen in Mexicali Rose v. Superior Court, ${ }^{161}$ where the court refused to follow the lead of more plaintiff-orientated jurisdictions when dealing with "natural" substances found in restaurant food. There, a patron claimed to suffer throat injuries when he swallowed a one inch chicken bone that unexpectedly appeared in his chicken enchilada. Application of strict liability via the consumer expectations test, so much touted in Barker, might well have been justified by the court on the grounds that, since the victim had no warning, the defendant was best situated to avoid these sorts of injuries or spread the risk when they inevitably occurred. However, the court

155. Id. at 303 .

156. Id. at 308 .

157. Id. at 309.

158. Soule, 882 P.2d at 310 and n.7.

159. An advantage, by the way, that I understand experienced plaintiffs' lawyers will never rely upon unless they are completely unable to come forward in their part of the case with alternative design proposals.

160. Note that the court in Soule ultimately decided that giving the consumer expectations test instruction was harmless error since the plaintiff so clearly emphasized fault-based theories-bad welding and bad design-in the presentation of her case. 882 P.2d at 310-12.

161. 822 P.2d 1292 (Cal. 1992). 
concluded that when the substance is "natural" to the food, as a bone is natural to chicken, the victim is not entitled to expect complete safety and hence may only proceed against the defendant in negligence. ${ }^{162}$

One final fact-specific product injury case is also worth noting. In Ramirez v. Plough, Inc., ${ }^{163}$ the court decided that a children's aspirin was not a defective product when the manufacturer provided the warnings only in English even though it widely advertised and sold the product in parts of the state where large numbers of monolingual Spanish speakers lived. The court rejected the pro-plaintiff result of an earlier New Jersey decision on similar facts and instead decided that drug manufacturer compliance with federal and state warning regimes should, as a matter of law, dictate that the product was not defective. ${ }^{164}$ This decision was not a matter of federal pre-emption, but rather the court's own, very self-conscious, choice to opt for a clear uniform rule, rather than allow the jury to decide the issue of adequacy of the warning from the facts on a case-by-case basis.

Although the new court in Ramirez does in the products liability area what I earlier emphasized it has been doing in negligence cases-i.e., adopting rules of law that take cases from the jury-I should acknowledge here that several of the other product liability cases I have discussed go the other way. That is, in rejecting strict liability for negligence, in for example, Mexicali Rose and Peterson (the hotel bathtub case), as well as in the cases discussed above that reject the "consumer expectations" test, the court, all the while making the law more pro-defendant, nonetheless creates a role for the jury.

\section{E. The Boundaries of NIED Claims}

A sharp change of direction also marked the new court's treatment of NIED cases. In Thing $v$. La Chusa, ${ }^{165}$ the court effectively overruled the Ochoa approach established at the end of the Bird era. In Thing, a mother heard about an accident involving her child and arrived at the scene moments later to find her badly injured child lying in the road. The mother sued the driver who ran over her child for NIED, but the court rejected the claim. ${ }^{166}$ Rebuffing the way Ochoa had treated the problem, the court resurrected the Dillon factors as

162. See id. at 1294.

163. 863 P.2d 167 (Cal. 1993).

164. See id. at 178.

165. 771 P.2d 814 (Cal. 1989).

166. See id. at 829-30. 
absolute legal requirements in NIED cases. ${ }^{167}$ No longer were those factors merely guidelines to indicate the sorts of factors that would help assure the genuineness and seriousness of the plaintiff's emotional distress. In this way, returning to one of my main themes here, power was removed from the jury and given to the trial judge who is enabled to rule for defendants in appropriate cases as a matter of law.

Even before Thing, the new court expressed its desire to restrict the availability of NIED claims. In Elden v. Sheldon, ${ }^{168}$ the court rejected a lawsuit by an unmarried heterosexual domestic partner who witnessed the negligent killing of her cohabitant when in a car together. Once more adopting a clear legal rule rather than allowing the jury to make an individualized judgment about the closeness of the relationship, the court announced that NIED suits were restricted to those who are legally married to the direct victim of the defendant's fault. 169 Later, in Christensen v. Superior Court, ${ }^{170}$ the new court adopted a restricted rule to govern who might sue for emotional distress arising from the negligent (or even intentional) mishandling of a decedent's remains, thereby narrowing the class of valid claimants who had been recognized by the court of appeals.

This is not to say that no plaintiffs won their NIED cases before the new court. In Marlene F. v. Affiliated Psychiatric Medical Clinic, Inc. ${ }^{171}$ the court concluded that a mother had a cause of action for NIED against a therapist who was counseling both her and her sons (after the therapist allegedly sexually molested the sons). It appears that the mother's own professional relationship with the therapist gave her the "direct victim" status required by prior case law. ${ }^{172}$ Furthermore, in Burgess v. Superior Court, ${ }^{173}$ the same approach allowed a mother to state an NIED claim against a doctor who negligently injured her child in the course of delivering the baby. Since the doctor was hired by her, she was a "direct victim." 174

However, the court called a halt to this development in Huggins $v$. Longs Drug Stores California, Inc. ${ }^{175}$ Parents in that case unwittingly injured their son by giving him a prescription overdose because the

167. Id. at 820. See also Dillon v. Legg, 441 P.2d 912 (Cal. 1968) (allowing recovery in certain circumstances by those who witness a close relative's harms).

168. 758 P.2d 582 (Cal. 1988).

169. See id. at 585-86.

170. 820 P.2d 181 (Cal. 1991).

171. 770 P.2d 278 (Cal. 1989).

172. See id. at 281.

173. 831 P.2d 1197 (Cal. 1992).

174. See id. at 1203.

175. 862 P.2d 148 (Cal. 1993) 
defendant pharmacy had misinstructed them as to the proper dosage. They sued for NIED but the court refused to treat them as "direct victims." 176 As the majority saw it, the parents were customers on behalf of their child, but they were not patients of the pharmacy in the conventional sense. ${ }^{177}$

The court also denied NIED recovery in Potter $v$. Firestone Tire and Rubber Co., ${ }^{178}$ where a group of landowners brought suit against a tire manufacturer for fear of acquiring cancer from the hazardous wastes the manufacturer dumped in a nearby landfill. The court held that, barring physical injury or illness, a plaintiff must prove a fear based on reliable medical and scientific opinion that he or she is more likely than not to develop cancer in the future due to exposure. ${ }^{179} \mathrm{My}$ point here is that we yet again see the court taking upon itself the decision as to where to draw the boundary around NIED claims, in contrast to the direction the Bird Court seemed to be moving in Ochoa.

\section{F. Other Areas of Tort Law: Win Some, Lose Some}

\section{Assumption of Risk}

In Knight v. Jewett, ${ }^{180}$ the court recognized that some so-called "assumption of risk" cases are really better understood as "comparative fault" cases (in which the careless victim should receive a partial recovery from the also careless injurer), whereas other cases are better understood as "no duty" cases (in which the victim should recover nothing). ${ }^{181}$ It would have been better, in my view, had the court just abolished the use of the "assumption of risk" label and allocated the cases to the other appropriate doctrinal categories. ${ }^{182}$ The court did not do that. More importantly for my purposes here, it chose to attach the "no duty/assumption of risk" label in a sweeping way to recreational injury cases. ${ }^{183}$

In Knight, the plaintiff and defendant were playing a casual game of "touch" football. According to the victim, she had already told the defendant to stop playing so roughly and he promised to be more

176. See id. at 150.

177. See id. at 154.

178. 863 P.2d 795 (Cal. 1993).

179. See id. at 800 .

180. 834 P.2d 696 (Cal. 1992).

181. Although the court did not acknowledge it, still other "assumption of risk" cases are better understood as "no breach" cases and perhaps "no proximate cause" cases.

182. See generally Stephen D. Sugarman, Assumption of Risk, 31 VAL. U. L. REV. 833 (1997) (discussing alternatives to the "assumption of risk" label such as informed consent, no duty rules, and comparative negligence).

183. See Knight, 834 P.2d at 708-09. 
careful when, on the next play, he knocked her down, stepped on her hand, and injured her. In what I view as a dubious empirical judgment, the court claimed "vigorous participation in such sporting events likely would be chilled if legal liability were to be imposed on a participant on the basis of his or her ordinary careless conduct. . . . [I]mposition of legal liability for such conduct might well alter fundamentally the nature of the sport." 184 In short, no duty was to lie apart from "conduct that is so reckless as to be totally outside the range of the ordinary activity involved in the sport." 185 Once more, the court here adopts a rule pursuant to which, as a matter of law, certain victims will not recover, thereby denying the plaintiff the opportunity to convince a jury that, under all the circumstances, the defendant's conduct was socially unacceptable. I do not mean to suggest that this is the wrong function for a "no duty" rule to serve, but rather to indicate my disagreement with the policy judgment that recreational injuries are an appropriate place for such a "no duty" rule.

Apparently, to make sure that the lower courts get the point, the court revisited the same basic issue three more times to emphasize the idea that in the typical recreational injury case, juries are not to decide whether, in the specific setting, this defendant had actually been unreasonably careless. The first was Ford $v$. Gouin, ${ }^{186}$ the companion case to Knight, which involved a water skier who was injured and sued the driver of the boat that was pulling him-on the grounds the driver carelessly drove too close to the riverbank. ${ }^{187}$ The second was Parsons v. Crown Disposal Co., ${ }^{188}$ where the plaintiff was thrown from his horse after loud noises from a nearby garbage truck frightened the horse. ${ }^{189}$ The third was Cheong v. Antablin, ${ }^{190}$ where friends skiing together crashed into each other, injuring the plaintiff, who sued his fellow skier claiming negligence on the part of the defendant. ${ }^{191}$

\section{Other}

As indicated already, not all plaintiffs lost their cases before the new court. For example, in Neighbarger v. Irwin Industries, Inc., ${ }^{192}$ the court refused to apply the so-called "firefighter's rule" (which bars

\footnotetext{
184. See id. at 710.

185. Id. at 711 .

186. 834 P.2d 724 (Cal. 1992).

187. See id. at 726.

188. 936 P.2d 70 (Cal. 1997).

189. See id. at 71.

190. 946 P.2d 817 (Cal. 1997).

191. See id. at 819.

192. 882 P.2d 347 (Cal. 1994).
} 
recovery as a matter of law) to private employees who were injured while battling a negligently set fire (restricting the rule's reach to public firefighters). ${ }^{193}$ In Alcaraz $v$. Vece, ${ }^{194}$ the court ruled in favor of a tenant plaintiff who sued his landlord after stepping into a water meter box with a missing or broken cover. The box was located in the front lawn of the property, but technically on the property owned by the city, not the defendant. The court concluded (4-3) that if the defendant exercised control over that adjacent property that was not noticeably separate from his, he would have a duty to warn his tenants of dangers on that property. ${ }^{195}$ These decisions (and others already noted above) make clear that the new court is not single-mindedly pro-defendant; rather, these two cases at least show the judges at work trying to work out in a sensible way the details of negligence law as it applies to newly presented situations. ${ }^{196}$

The potentially most pro-plaintiff decision from the past twelve years, in my judgment, is Mitchell v. Gonzales, ${ }^{197}$ in which the court decided that trial courts should no longer give the "but for" jury instruction on causation, but should instead give a "substantial factor" instruction. ${ }^{198}$ This particular case involved the drowning of one of three young children who had been playing together on a paddle board in water deeper than they were tall. It appears that there may have been some misunderstanding by the jury about the idea that more than one cause can be a proximate cause of an injury. ${ }^{199}$ But this decision could be enormously beneficial to plaintiffs in other cases (and highly disruptive of traditional tort doctrine) if the shift in jury instructions here ordered also undermines (as it would appear to) traditional notions about "cause in fact." The court, in passing, tries to make light of this possibility, saying that "[i]f the conduct ... had nothing at all to do with the injuries," it could not be a substantial factor in causing them. ${ }^{200}$ Yet this misses some far more difficult

193. See id. at $355-56$.

194. 929 P.2d 1239 (Cal. 1997).

195. See id. at 1253.

196. Two more exotic cases were faced by the new court. First, San Diego Gas and Electric v. Superior Court, where plaintiffs sued a public utility alleging injuries from exposure to electromagnetic fields created by power lines adjoining their property. 920 P.2d 669 (Cal. 1996). The court barred the action under Public Utility Code Section 1759 as an impermissible interference with the Public Utility Commission's broad regulatory authority. Id. at 704-05. Second, Moore v. Regents of the University of California, was a very special "informed consent" case in which the plaintiff successfully claimed that the defendants improperly used his cells for potentially lucrative medical research without obtaining his prior permission. 793 P.2d 479, 480 (Cal. 1990).

197. 819 P.2d 872 (Cal. 1991).

198. See id. at 877-82.

199. See id. at 875-76.

200. Id. at 878 . 
problems than the court seems to acknowledge. However, this is not the occasion to go into these matters. 201

\section{G. Bad Faith Retreat}

Finally, again as an aside, let me simply note that the new court has largely gutted the "bad faith" law that was so steadfastly erected during the Bird era and earlier. In Freeman \& Mills v. Belcher Oil, ${ }^{202}$ the court overruled the Bird Court's 1984 decision in Seamans. In Moradi-Shalal v. Fireman's Fund Insurance Cos., ${ }^{203}$ the court overruled Royal Globe v. Superior Court, ${ }^{204}$ an earlier California Supreme Court decision which had allowed tort victims to bring bad faith claims against their defendant's insurers when the latter refused to settle. In Foley $v$. Interactive Data Corp. ${ }^{205}$ the court sharply curtailed the tort rights of employees claiming "wrongful discharge."206 Moreover, on a related front, the court in Cedars-Sinai Medical Center v. Superior Court ${ }^{207}$ rejected the claimant's plea to create a "new" tort for the "spoilage of evidence" in the context of a plaintiff asserting the defendant had destroyed records that were crucial to his case. ${ }^{208}$

\section{Conclusion}

I have not tried to count up the numbers in any precise way, but my recitation should make clear that the rate of success by tort plaintiffs in the California Supreme Court is dramatically different over the past dozen years than it was at the end of the Bird era. Calabresian thinking about enterprise liability as a way of dealing with the cost of accidents is currently dead in the Golden State. At the same time, we have lots of new rules and judicial decisionmaking in cases that, in prior years, would have gone to juries with vague instructions about fault attached. And so, I hope I have shown that, in their very different ways, both the old and new courts have made and un-made a new law of torts.

201. For another more defense-oriented foray by the court into the world of "causation," see Rutherford v. Owens-Illinois, Inc., 941 P.2d 1203, 1214-22 (1997).

202. 900 P.2d 669 (Cal. 1995).

203. 758 P.2d 58 (Cal. 1988).

204. 592 P.2d 329 (Cal. 1979).

205. 765 P.2d 373 (Cal. 1988).

206. Id. at 384-86.

207. 954 P.2d 511 (Cal. 1998).

208. Id. at 515-17. 
[Vol. 49:455 